\title{
PRL wobec rozszerzenia Wspólnot Europejskich o Hiszpanię i Portugalię (1962-1986)
}

W latach osiemdziesiątych XX wieku w Europie zachodniej miało miejsce rozszerzenie Wspólnot Europejskich o Hiszpanię i Portugalię, nazywane, tak jak w przypadku Grecji, rozszerzeniem południowym. Poprzedzone ono było długimi i niełatwymi negocjacjami trwającymi łącznie ponad 20 lat. Początkowo, przeszkodą na drodze do członkostwa w EWG obu iberyjskich krajów były kwestie polityczne, a konkretnie dyktatorska forma sprawowania władzy reprezentowana w Hiszpanii przez generała Francisco Franco, a w Portugalii przez António de Oliveira Salazara. Była ona nie do pogodzenia z demokratyczną formą rządów państw członkowskich EWG. W późniejszym okresie niemałą rolę zaczęły odgrywać argumenty ekonomiczne. Członkowie EWG uzasadniali, że: „członkostwo w tej organizacji powinno być przyznawane krajowi będącemu na tym samym poziomie rozwoju gospodarczego co kraje Wspólnego Rynku. W przeciwnym bowiem wypadku kraj taki nie jest w stanie przyjąć na siebie wszystkich zobowiązań wynikających z dotychczasowego stopnia integracji krajów członkowskich" (Bernatowicz-Bierut, 1978, s. 174).

Władza ludowa w Polsce bacznie obserwowała proces zbliżania obu iberyjskich krajów do EWG i Europy zachodniej. Zważywszy na to, że: „proces dochodzenia do członkostwa Portugalii we Wspólnotach Europejskich odbywał się niejako w cieniu jej większego sąsiada - Hiszpanii”, (Szymczyński, 2009, s. 103), polskie władze więcej uwagi poświęcały hiszpańskiej, a nie portugalskiej akcesji do EWG. Wydarzenia te z dużym zainteresowaniem szczególnie śledziło Ministerstwo Spraw Zagranicznych PRL oraz Ministerstwo Handlu Zagranicznego. Od początku lat sześćdziesiątych, aż do 1986 roku trwała długa i ożywiona dyskusja pomiędzy resortami odpowiedzialnymi za koordynację i prowadzenie polskiej polityki zagranicznej oraz handlu zagranicznego na temat konsekwencji rozszerzenia Wspólnot Europejskich o wspomniane kraje. W tajnych notatkach i poufnych pismach nadsyłanych z placówek dyplomatycznych z: Madrytu, Rzymu, Paryża do Departamentu IV MSZ (Europa Zachodnia) rozważano jakie konsekwencje może mieć włączenie obu krajów do Wspólnot Europejskich. W kuluarach salonów dyplomatycznych głoszono pogląd, że kolejne rozszerzenie EWG w konsekwencji doprowadzi do powstania trzeciego mocarstwa na świecie tym razem europejskiego, oprócz ZSRR i USA, a w przyszłości powołania na starym kontynencie Stanów Zjednoczonych Europy.

Z perspektywy władz PRL akcesja obu krajów do jednoczącej się Europy była procesem niezwykle skomplikowanym. W płaszczyźnie gospodarczej głównym polem konfliktów w relacjach EWG z Hiszpanią i Portugalią pozostawały problemy dostosowania rolnictwa obu krajów do wymogów Wspólnot oraz wsparcia finansowego i technologicznego dla ich przemysłu. W tym punkcie istotnym problemem było sta- 
nowisko głównie Francji i Włoch obawiających się o przyszłość rodzimego rolnictwa. Nie mniej ważnym zagadnieniem były wewnętrzne spory pomiędzy najbardziej wpływowymi państwami EWG: Francją, RFN, Wielką Brytanią, Włochami i Belgia, które podczas trwającego procesu negocjacyjnego, zdaniem władz PRL, kierowały się głównie partykularnymi interesami, a nie interesem wspólnotowym.

W Polsce próbowano również ocenić jakie mogą być skutki rozszerzenia EWG o Hiszpanię i Portugalię dla kooperacji państw socjalistycznych w ramach Rady Wzajemnej Pomocy Gospodarczej oraz Układu Warszawskiego. W tym miejscu warto nadmienić, że władza ludowa oceniała, że warunkiem członkostwa Hiszpanii w EWG jest rychła akcesja kraju do NATO, co ostatecznie nastapiło w 1982 roku. W przypadku Portugalii proces ten nie byłby możliwy bez uprzedniej zgody Wielkiej Brytanii, która przynajmniej od pokoju w Utrechcie w 1712 roku sprawowała nad Lizboną nieformalną opiekę.

Poprzez pryzmat członkostwa Hiszpanii i Portugalii w EWG analizowano także bilans korzyści i kosztów członkostwa obu krajów dla gospodarki polskiej. Ważny głos w sprawie zbliżenia obu iberyjskich krajów do EWG zabrali nie tylko polscy dyplomaci, ale również publicyści organów prasowych PRL, m.in.: „Trybuny Ludu”, „Życia Warszawy”, „Polityki”, „Tygodnika Demokratycznego”. Już od początku lat sześćdziesiątych, polskie społeczeństwo względnie systematycznie informowane było o postępach w negocjacjach i problemach, które musiały zostać przezwyciężone przez zainteresowane strony: Hiszpanię i Portugalię oraz kraje członkowskie EWG.

\section{Przed akcesją - droga Hiszpanii i Portugalii do EWG}

Geneza akcesji obu iberyjskich krajów: Hiszpanii i Portugalii do EWG sięga końca lat pięćdziesiątych XX wieku. U podstaw tych starań legły przesłanki zarówno polityczne, jak i ekonomiczne.

Tuż po zakończeniu II wojny światowej Hiszpania stanęła przed koniecznością otwarcia kraju na świat i wyjścia z izolacji międzynarodowej. Zimna wojna, a zwłaszcza traktat madrycki ze Stanami Zjednoczonymi i konkordat z Watykanem z 1953 r. były kamieniami milowymi na drodze do przynajmniej częściowego zyskania zaufania międzynarodowego. W nowych uwarunkowaniach zaczęto więc poszukiwać dróg, które miały poprowadzić kraj ku rozwojowi gospodarczemu i stabilizacji. W związku z tym generał Franco odszedł od polityki autarkii w gospodarce i przeniósł swoje zainteresowania na ścisłą współpracę z Europejską Wspólnotą Gospodarczą. W 1959 roku podjął decyzję o powołaniu Międzyministerialnej Komisji ds. EWG i Euratomu, która miała ocenić wpływ wspólnej polityki handlowej EWG na gospodarkę hiszpańską. Kolejnym krokiem przybliżającym Madryt do kooperacji ze Wspólnotami Europejskimi było powołanie przez Franco ambasadora Hiszpanii przy EWG, który 9 lutego 1962 roku złożył w Brukseli wniosek o stowarzyszenie kraju ze Wspólnotami Europejskimi. Decyzję Franco wymusiły istotne okoliczności. W latach sześćdziesiątych zaczął on zdawać sobie sprawę z konsekwencji politycznych i gospodarczych dla Hiszpanii wynikających z izolowania kraju na arenie międzynarodowej. Sytuację Hiszpanii pogarszał fakt, że od 1957 roku EWG zaczęła realizować Wspólną Politykę 
Rolną, która mocno dawała się we znaki hiszpańskiej gospodarce, gdyż - jak zauważa G. Bernatowicz-Bierut: „,W związku z przyjęciem przez kraje EWG wspólnej polityki rolnej ich udział w hiszpańskim eksporcie zmniejszył się o 5\%. Ponadto w nowej sytuacji hiszpańskie rolnictwo nie byłoby w stanie wytrzymać konkurencji z rolnictwem włoskim (Bernatowicz-Bierut, 1978, s.174).

Hiszpański dyktator miał również świadomość, że kraj po zbliżeniu do EWG ma szansę na pozyskanie ogromnych funduszy, które mogłyby zmodernizować przestarzałą gospodarkę oraz wesprzeć nisko wydajny i niekonkurencyjny hiszpański przemysł. Tym bardziej, że na początku lat sześćdziesiątych, a więc jeszcze przed złożeniem wniosku o akcesję rozwijający się hiszpański przemysł potrzebował wsparcia z zachodu i otrzymał je, jednak kosztem wzrostu deficytu w hiszpańskim handlu zagranicznym. Potwierdzeniem autentycznych starań Hiszpanii o zbliżenie z Europą zachodnią oraz chęci wyjścia kraju z izolacji miało być członkostwo kraju w Organizacji Narodów Zjednoczonych (1958), Organizacji Europejskiej Współpracy Gospodarczej (1959), Międzynarodowym Funduszu Walutowym (1959), Międzynarodowym Banku Odbudowy i Rozwoju (1959). Zaangażowanie Hiszpanii we współpracę międzynarodową miały potwierdzić obranie przez frankistowski reżim kierunku liberalnego w gospodarce i otwarcie kraju na handel międzynarodowy. W tym miejscu warto nadmienić, że bez finansowego i moralnego wsparcia ze strony USA metamorfoza w hiszpańskiej polityce zagranicznej nie miałaby miejsca. Ważnym punktem tej przemiany były stosunki polityczno-wojskowe USA-Hiszpania obwarowane wspomnianym Paktem Madryckim podpisanym przez obie strony w 1953 roku. Pakt przewidywał wydatną pomoc finansową dla Hiszpanii w zamian za użytkowanie przez USA baz lotniczych i baz wojskowych dla wojsk USA i NATO. Innymi działaniami podjętymi przez rząd w Madrycie, aby przybliżyć kraj do współpracy ze Wspólnotami Europejskimi, było wdrożenie pod koniec lat pięćdziesiątych Planu Stabilizacji pozytywnie ocenianego przez kraje OEEC i nazywanego: ,pierwszym po wojnie domowej rzeczywistym krokiem w kierunku otwarcia Hiszpanii na świat (Szymczyński, 2009, s. 52), a także 4-letniego Planu Rozwoju Gospodarczego i Społecznego przewidzianego na lata 1964-1968.

W innym iberyjskim kraju - Portugalii - sytuacja wyglądała względnie podobnie jak u sąsiada Hiszpanii. Aż do 1968 roku, a więc przez 40 lat życie polityczne i ekonomiczne kraju koncentrowało się wokół jednej osoby - również dyktatora Antonio de Oliviera Salazara. Jak zauważa Dominika Bocheńczyk-Kupka okres jego rządów charakteryzował się nacjonalizmem, brakiem reform gospodarczych (dyktator był zwolennikiem gospodarki feudalnej) oraz umiarkowanym izolacjonizmem (BocheńczykKupka, 20.08.2016). Pomimo, że Portugalia była krajem założycielem NATO i weszła w skład konkurencyjnego wobec EWG Europejskiego Stowarzyszenia Wolnego Handlu, początkowo nie zależało jej na jeszcze większym zbliżeniu z zachodem. Lizbona była bardziej zainteresowana zabezpieczeniem swoich interesów gospodarczych w koloniach. W późniejszych latach, kiedy utrwalenie izolacji gospodarczej groziło krajowi Portugalia zaczęła rozważać korzyści, jakie może przynieść kooperacja ze Wspólnotami Europejskimi.

Wyżej wymienione czynniki skłoniły oba kraje do złożenia wniosków o członkostwo we Wspólnotach Europejskich już na początku lat sześćdziesiątych. Jak już 
wcześniej wspomniano, 9 lutego 1962 roku Hiszpania złożyła na ręce sekretarza generalnego Rady Ministrów EWG wniosek o stowarzyszenie kraju ze Wspólnotami Europejskimi. Wniosek ten nie wzbudził jednak zainteresowania członków EWG, został odrzucony przez Parlament Europejski, głównie z powodu dyktatorskiej i niedemokratycznej formy sprawowania rządów tym w kraju. W związku z zaistniałą sytuacją rząd hiszpański złożył podobne pismo 14 lutego 1964 roku i dopiero wtedy temat akcesji pojawił się w dyskusjach we WE. Przez sześć lat trwały rozmowy Hiszpanii z EWG, które zaowocowały podpisaniem 20 marca 1970 roku jedynie Układu Preferencyjnego ułatwiającego handel między stronami. Droga Hiszpanii do pełnego członkostwa kraju w EWG wydawała się być długa i trudna.

Z kolei Portugalia, pierwszy wniosek o członkostwo w EWG złożyła 4 czerwca tego samego roku i z podobnych powodów co wniosek hiszpański jej kandydatura nie znalazła uznania w oczach Rady Ministrów Wspólnot Europejskich. W 1971 roku rząd portugalski ponowił prośbę, tym razem o status członka stowarzyszonego z EWG. Podobnie jak w przypadku Hiszpanii WE zgodziły się na podpisanie Układu Preferencyjnego w handlu, który sygnowano w 1972 roku. W tym okresie perspektywa pełnoprawnego członkostwa była jednak - podobnie jak w przypadku Hiszpanii - bardzo odległa.

Już od początku lat sześćdziesiątych, w polskiej publicystyce pojawiały się interesujące informacje na temat zbliżenia Hiszpanii i Portugalii do Europy zachodniej, a w szczególności do EWG.

W 1962 roku Artur Hajnicz na łamach „Życia Warszawy” nawiązał do przeprowadzanych przez generała Franco radykalnych zmian w hiszpańskim rządzie i zwrócił uwagę na reakcje prasy zagranicznej komentującej te wydarzenia. Na łamach artykułu $W$ kręgu starych przyjaciół zaznaczył, że w odpowiedzi na nie Franco wybuchł wściekłością i zaaresztował wielu przeciwników reżimu z różnych środowisk: liberalnych, chadeckich, monarchistycznych, a także separatystycznych. W tym czasie opozycja w Hiszpanii organizowała wiele takich wieców wymierzonych przeciwko dyktaturze Franco, które reżim frankistowski tłumił i pacyfikował. Co ciekawe, na jednym z wieców, opozycjoniści wysunęli postulat nieprzyjmowania Hiszpanii do EWG, dopóki panuje tam dyktatorski rząd generała. Zdaniem Hajnicza sytuacja ta była wybitnie nie na rękę dyktatorowi, który właśnie w 1962 roku postanowił złożyć wniosek o stowarzyszenie kraju z EWG. W dalszej części artykułu autor przybliżył sytuację gospodarczą i uwypuklił problemy gospodarcze iberyjskiego kraju: „w ostatnich dwóch latach poziom gospodarki hiszpańskiej jest bardzo niski [...] ocenia się, że w ostatnich latach ponad milion chłopów hiszpańskich udało się na emigracyjną tułaczkę do Ameryki Południowej [...] Robotnicy hiszpańscy są najgorzej płatni w Europie. Setki tysięcy ludzi pracy udaje się na roboty sezonowe do Europy centralnej (Równocześnie, w tym biednym kraju rozdmuchano niesłychanie wydatki wojskowe [...] dalszą część budżetu pochłania aparat bezpieczeństwa [...] na oświatę przeznacza się zaledwie $0,9 \%$ dochodów" (Hajnicz, 1962a, s. 3). W kolejnych fragmentach artykułu publicysta zauważył, że dla generała Franco zakładane członkostwo w EWG miało być swoistym panaceum na wszystkie bolączki hiszpańskiej gospodarki. Zauważył też, że aby dodać otuchy generałowi i w pewnym sensie ,rozgrzeszyć” jego działania, do Madrytu przyjechało wiele delegacji zagranicznych, m.in. z RFN, Belgii, Wielkiej Brytanii, które zapowie- 
działy, że nie pozwolą izolować Hiszpanii i zapraszają ją do: kręgu „,nowych - starych przyjaciół" - EWG.

Ten sam autor ocenił również portugalskie starania o członkostwo w EWG na początku lat sześćdziesiątych. W 1962 roku na łamach „Życia Warszawy” w artykule Ostatnie podanie Hajnicz zauważył, że Portugalia złożyła wniosek o akcesję do EWG i uczyniła to kilka miesięcy po Hiszpanii. Jego zdaniem głównym motywem, którym kierowała się Portugalia w staraniach o członkostwo we Wspólnotach Europejskich były względy gospodarcze. W artykule autor uzasadnił, że Portugalia liczy, że po akcesji do EWG otrzyma dotacje na rolnictwa oraz konieczne finansowe wsparcie dla rodzimego przemysłu. Podkreślił również, że wśród Portugalczyków panuje przekonanie, że bez akcesji z EWG kraj pozostanie na peryferiach Europy. Na łamach dziennika autor wymienił te produkty, które kraj głównie produkuje: sardynki, oliwki, korek, portwein wolfram i produkty bawełniane, które są eksportowane głównie do portugalskich kolonii. Jak zauważył Hajnicz: „,poziom portugalskiego rolnictwa jest bardzo niski, a kraj, którego większość stanowią chłopi importuje stale pszenicę, mięso, cukier tytoń, i inne produkty rolne [...]" wysoki deficyt handlowy kraju, który w sposób nieudolny uzupełniany był dochodami z: „wyzysku kolonii: Mozambiku i Angoli” (Hajnicz, 1962b, s. 2). W dalszej części artykułu publicysta dziennika podkreślił, że w 1960 roku Portugalia zdecydowanie więcej towarów importowała ze Wspólnot Europejskich, aniżeli eksportowała do krajów EWG. Jego zdaniem w obecnej sytuacji ewentualne przyłączenie Portugalii do EWG będzie się wiązało z katastrofą dla gospodarki portugalskiej. Jednocześnie dodał, że pozostanie kraju na obrzeżach EWG będzie również niekorzystne dla iberyjskiego kraju.

Od momentu złożenia przez Portugalię wniosku o członkostwo w EWG polskie służby dyplomatyczne przyglądały się rozwojowi stosunków pomiędzy stronami.

24 stycznia 1963 roku Radca do spraw Prasowych ambasady PRL w Paryżu Jaromir Ochęduszko przesłał do dyrektora DEP. IV MSZ (Europa Zachodnia) w Warszawie Mieczysława Łobodycza tajną notatkę zatytułowaną: Tendencje rozwojowe gospodarki Portugalii w zwiqzku z projektem przystapienia do EWG.

Już na wstępie notatki Ochęduszko podkreślił, że obecny rok 1963 jest kluczowy w kwestii ewentualnego przystapienia kraju do Wspólnot. Wynikało to z podjętych przez rząd w Lizbonie szeregu środkach polegających m.in., na ingerencji w gospodarkę. Ponadto w przyszłym roku - 1964 - ma się zakończyć realizacja planu gospodarczego, który ma otworzyć gospodarkę portugalską i osiagnąć minimum 5\% wzrostu gospodarczego - zgodnie z sugestiami OECD (Ochęduszko,1963, Archiwum MSZ (dalej AMSZ), DEP. IV, zespół 17, wiązka 32).

W dalszej części tajnej notatki polski dyplomata podkreślił, że rząd w Lizbonie zdaje sobie sprawę z tego, że niektóre decyzje będą ciężkie dla rodzimej gospodarki, szczególnie dla tych gałęzi i przedsiębiorstw, które korzystały z ochrony celnej. „Realizacja nowych postanowień będzie nawet wymagała, obok wszechstronnej informacji, szerokiego stosowania perswazji wobec opornych przedsiębiorstw" (Ibidem). Późniejszy, wieloletni ambasador PRL w Rumunii dodał również, że wzrost gospodarczy Portugalii w 1961 wyniósł 7,1\% i jest to zasługą głównie rozwoju przemysłu oraz sektora usług, a nie rolnictwa, które Ochęduszko nazwał piętą achillesową gospodarki portugalskiej. Według szacunków przynosiło ono rocznie zaledwie 3,4\% dochodu go- 
spodarce. W tym miejscu autor zaznaczył, że rząd w Lizbonie miał zamiar rozwiązać ten problem poprzez położenie większego nacisku na hodowlę i sadownictwo w gospodarce. W ostatniej części tajnej notatki radca prasowy ambasady PRL w Paryżu podkreślił również, że w lutym 1963 roku ma się odbyć posiedzenie, podczas którego będzie wysłuchana delegacja portugalska i przedstawione warunki akcesji kraju do EWG, jakie proponuje rząd w Lizbonie. Podkreślił, że: „przebieg tych rokowań uzależniony jest od rozwiązania sprawy Wielkiej Brytanii" (Ibidem).

Pod koniec lat sześćdziesiątych polscy dyplomaci monitorowali zamiary wdrożenia przez Hiszpanię Planu Rozwoju Gospodarczego i Społecznego Hiszpanii, który miał przybliżyć kraj do wymogów stawianych przez EWG.

14 lutego 1967 roku pracownik Przedstawicielstwa Konsularno-Handlowego w Madrycie Stanisław Rogulski przesłał do dyr. DEP. IV MSZ Mieczysława Łobodycza tajną notatkę zatytułowaną: Sytuacja gospodarcza Hiszpanii. W dokumencie tym szczegółowo przeanalizował aktualne starania Hiszpanii o włączenie kraju do EWG. Już na wstępie zwrócił uwagę, że od końca lat pięćdziesiątych sytuacja gospodarcza i polityczna w Hiszpanii uległa zmianie. Wynikało to głównie z wprowadzenia w kraju w 1959 roku Planu Stabilizacji, którego jednym z założeń było zahamowanie inflacji i uzdrowienie finansów publicznych. W związku z powyższym w kraju zdewaluowano peso i zamknięto nierentowne przedsiębiorstwa. Jak do tej pory: „średnia rentowność przemysłu hiszpańskiego była znacznie niższa od przemysłu krajów Wspólnego Rynku, a Hiszpania zmierzała do koncentracji i modernizacji przemysłu" - podkreślił (Rogulski, 1967, A MSZ, DEP IV MSZ, Zespół 17, wiązka 24). Z biegiem czasu Hiszpania przestała być krajem autarkicznym i wyszła z izolacji międzynarodowej. W dalszej części notatki Rogulski zauważył również, że z biegiem nasilenia się zjawiska zimnej wojny Hiszpania przewartościowała również swoją politykę zagraniczną. Nawiązała ona stosunki dyplomatyczne z innymi państwami kapitalistycznymi, a krajem zainteresowały się również Stany Zjednoczone, które zamierzały wykorzystać dogodnie położone terytorium do celów wojskowych. Względna poprawa stosunków Hiszpanii z zachodnim supermocarstwem zaowocowała również napływem kredytów i innej pomocy gospodarczej dla kraju. Wzmocniła również prestiż Hiszpanii i rozbudziła nadzieję wśród krajów zachodnich na normalizację w kraju i odejście od autorytarnego charakteru państwa. Jego zdaniem, kolejnym działaniem rządu hiszpańskiego zmierzającym do zacieśnienia relacji z krajami kapitalistycznymi Europy zachodniej było wdrożenie Planu Rozwoju Gospodarczego i Społecznego zaprojektowanego na lata 1964-1967. W ramach tego planu Hiszpania znacząco poprawiła relacje pomiędzy rodzimym eksportem a importem i przeprowadziła reformy walutowe, rozwinęła też branżę turystyczną. Jak zauważył Rogulski, od 1965 roku jednym z największych biorców towarów hiszpańskich był członek EWG - RFN, co jednak nie przełożyło się na poprawę bilansu płatniczego. Deficyt budżetowy był w dalszym ciagu wysoki. Madryt, częściowo rekompensował sobie finansowe straty wynajmując dla RFN bazy wojskowe oraz rozwijając współpracę wojskową z USA.

W dalszej części notatki Rogulski zaznaczył, że pomimo tego, że w ostatnich latach eksport Hiszpanii do krajów szóstki wzrósł pięciokrotnie - z 300 mln dolarów do 1500 milionów dolarów (Ibidem), w dalszym ciagu wysiłki Madrytu zmierzające do stowarzyszenia kraju z EWG nie dały rezultatu. W Madrycie oczekiwano bowiem, że 
powiązanie gospodarcze Hiszpanii z EWG umożliwiłoby krajowi dokonanie specjalizacji w produkcji i podniesienie jej na wyższy szczebel. ,Traktat Handlowy, który proponuje Komisja Wykonawcza EWG nie wystarcza jej” (Ibidem) - skomentował polski dyplomata. Koniec lat sześćdziesiątych nie spełnił więc oczekiwań Hiszpanów.

W podobnym tonie na temat ewentualnego członkostwa Hiszpanii w EWG wypowiedział się inny polski dyplomata, Wicedyrektor Departamentu Traktatów II Ministerstwa Handlu Zagranicznego Stanisław Długosz. W kwietniu 1967 roku przesłał on do DEP. IV MSZ w Warszawie notatkę zatytułowaną: Stosunki polsko-hiszpańskie i zauważył, że kolejny wniosek Hiszpanów o członkostwo w EWG z lutego 1967 roku został odrzucony, a Rada Ministerialna EWG złożyła projekt: ,jedynie preferencyjnego porozumienia handlowego polegającego na wzajemnym udzieleniu preferencji taryfowo-celnych na wybrane towary przemysłowe, ewentualnie niektóre artykuły rolne” ( Długosz, 1967, A MSZ, Departament IV, zespół 17, wiązka 24). Tak więc rozpoczęte przez Hiszpanię rozmowy z EWG na temat ewentualnego stowarzyszenia kraju z państwami szóstki nie powiodły się. Długosz przeanalizował tą sytuację również poprzez pryzmat stosunków relacji kraje kapitalistyczne-kraje socjalistyczne i dodał, że w wyniku niskiego udziału hiszpańskiego eksportu w stosunkach z EWG i EFTA stosunki handlowe z krajami socjalistycznymi nieznacznie się zmniejszyły.

W tym okresie temat ewentualnego członkostwa Hiszpanii w EWG podjęli również publicyści prasy polskiej.

Paweł Dubiela na łamach „Tygodnika Demokratycznego” przeanalizował cały okres dyktatorskich rządów generała Franco i zwrócił uwagę, że w obecnym 1967 roku wiele grup społecznych podjęło akcję protestacyjną przeciwko dyktaturze - przede wszystkim robotnicy i studenci, w co najmniej 13 miastach. Reżim odpowiedział aresztowaniami, a to zdaniem autora doprowadziło do zmniejszenia poziomu inwestycji zagranicznych. Bilans płatniczy pozostał ujemny, a ceny towarów podniosły się w górę. Dlatego też zdaniem autora: ,jedyną szansę uspokojenia nastrojów widzi Franco w szybkim polepszeniu sytuacji gospodarczej. Chce to osiagnąć poprzez przystapienie do Wspólnego Rynku, nad czym gorliwie pracują eksperci w Brukseli" (Dubiel, 1967, s. 1).

23 grudnia 1968 roku przedstawiciel Konsulatu Handlowego w Madrycie Edward Polański przesłał do DEP. IV MSZ notatkę zatytułowaną: Polityka zagraniczna Hiszpanii. Starał się w niej ocenić stan procesu włączania Hiszpanii do bloku zachodniego: EWG, ale również do NATO, gdyż w pewnym sensie dla Polańskiego oba te członkostwa były od siebie nieodłączne.

Już na wstępie notatki w interesujący sposób połączył motywacje politycznoobronne i gospodarcze Hiszpanii sugerując, że: ,uprzedzenia niektórych zachodnioeuropejskich społeczeństw do reżimu Franco stanowią przeszkodę w przyjęciu Hiszpanii do Sojuszu Atlantyckiego. A rządy tych krajów wykorzystują również istniejącą nieufność do Hiszpanii jako pretekst do niedopuszczenia jej do EWG, głównie na tle sprzeczności ekonomicznych"(Polański, 1968, A MSZ, DEP. IV, zespół 17, teczka 211, wiązka 24). Zdaniem autora państwa zachodnioeuropejskie niewłaściwie oceniają działania rządu hiszpańskiego. Nadmienił, że politykę zagraniczną Hiszpanii charakteryzuje elastyczność, oraz chęć odgrywania autonomicznej roli w polityce europejskiej, a nawet światowej: „opartej o przykład de Gaulle’a 
z inklinacją do wstąpienia na tory polityki niezaangażowania" (Ibidem). W opinii późniejszego charge' d'affairs ambasady PRL w Madrycie potwierdzała to akceptacja przez Hiszpanię procesu dekolonizacji oraz niezajęcie oficjalnego stanowiska w sprawie wydarzeń w Czechosłowacji z 1968 roku. W końcowej części notatki Polański podkreślił, że zasadniczym kierunkiem polityki zagranicznej Hiszpanii było i jest dążenie do przystąpienia do EWG.

W latach sześćdziesiątych hiszpańskie starania o akcesję do EWG lub ewentualne stowarzyszenie kraju ze Wspólnotami Europejskimi nie dawały rezultatu. W dalszym ciągu na stosunkach pomiędzy stronami ciążyły argumenty polityczne - dyktatorskie i niedemokratyczne rządy F. Franco. Z drugiej strony stosunki handlowe między stronami rozwijały się, a wskaźniki udziału krajów wspólnoty w obrotach handlowych Hiszpanii systematycznie wzrastały.

W obliczu tego, 12 marca 1970 roku EWG podpisała z Hiszpanią Układ Preferencyjny, który oparty został na art. 113 Traktatu Rzymskiego. Przewidywał on m.in. likwidację barier celnych między stronami.

24 czerwca 1970 roku Edward Polański przesłał z Madrytu do DEP. IV MSZ notatkę zatytułowaną: Hiszpania a EWG. Podkreślił w niej, że hiszpańskie środowiska dysponujące odpowiednim kapitałem przemysłowym: ,już w 1962 roku postulowały kurs na Wspólny Rynek. Stoją one na stanowisku, że wobec światowej już tendencji łączenia się państw w ugrupowania gospodarcze, samo izolowanie się może doprowadzić do samobójstwa ekonomicznego (Polański 1970, A MSZ, Zespół Akt Nabytek 27/76, wiązka 8). W dalszej części notatki Polański zauważył, że próby zbliżenia Hiszpanii do EWG rozbijały się o sceptyczne stanowisko Włoch czy Holandii obawiających się o własne rolnictwo lub negatywną reakcję społeczeństw Belgii lub Francji obawiających się reżimu frankistowskiego. Ostatecznie jednak, po zaakceptowaniu przez Radę Ministrów WE pełnomocnictwa do rokowań z Hiszpanią w 1967 roku zadecydowano o podjęciu rozmów na temat handlowego układu preferencyjnego z Hiszpanią. W opinii Polańskiego układ ,pozostawia Hiszpanii swobodę w odniesieniu do innych ugrupowań integracyjnych, nie zobowiązuje również Hiszpanii do zamrażania swych barier celnych pod warunkiem zachowania preferencji dla EWG" (Ibidem). W ramach zapowiadanego układu preferencyjnego obie strony: Hiszpania i EWG uzgodnily korzystne dla ich gospodarek koncesje zarówno na towary przemysłowe, jak i spożywcze. Na koniec notatki Polański ocenił, że układ preferencyjny jest korzystny dla przemysłu hiszpańskiego, a mniej dla rodzimego rolnictwa. Jego wejście w życie będzie oznaczało: ,poważny wysiłek dla gospodarki narodowej w przystosowaniu się do nowych warunków konkurencyjnych" (Ibidem).

Zdaniem pracownika Przedstawicielstwa Konsularno-Handlowego w Madrycie negocjowany układ preferencyjny, a w dalszej perspektywie zbliżenie Hiszpanii do WE, ma na celu zakotwiczenie kraju w Europie zachodniej ekonomicznie, jak również obronnie. W polityce wewnętrznej kraju miał być przesłanką do zdławienia reżimu frankistowskiego. Polański dokonał również oceny polsko-hiszpańskich stosunków gospodarczych. Zauważył, że w obliczu nie ujawniania list towarowych trudno jest ocenić skutki podpisania układu preferencyjnego dla Polski. Z całą pewnością można jednak stwierdzić, że zmniejszy się konkurencyjność polskich towarów na rynku hiszpańskim - zaznaczył. 
Zmieniająca się dynamicznie sytuacja w relacjach EWG-Hiszpania nie umknęła również uwadze prasie polskiej, na łamach której sugerowano, że rok 1970 jest dla Hiszpanii kluczowy, gdyż kraj stoi na rozdrożu.

W czerwcu 1970 roku Ignacy Krasicki na łamach ,Życia Warszawy” zwrócił uwagę, że Madryt w dalszym ciąu poszukuje właściwego wektora w polityce zagranicznej. Z jednej strony: „definiuje swoją tożsamość poprzez zajmowane kluczowe miejsce w basenie Morza Śródziemnego, ścisłe związki z Francją, a także poprzez więzi ze Wspólnym Rynkiem i innymi istniejącymi w Europie ugrupowaniami integracyjnymi” (Krasicki, 1970, s. 3). Z drugiej strony ze względu na dogodne położenie geopolityczne oraz wynajmowane Amerykanom bazy wojskowe jest zależny od polityki Waszyngtonu (Ibidem).

Początek lat siedemdziesiątych był znaczący również dla drugiego iberyjskiego kraju, który dążył do członkostwa we WE, gdyż w 1972 roku wynegocjowano Układ Preferencyjny, handlowy w stosunkach Portugalia-EWG. Przemiany polityczne i gospodarcze w kraju dostrzegli i ocenili również polscy dyplomaci.

W 1971 roku ambasador PRL w Rzymie Wojciech Chabasiński spotkał się w stolicy Włoch z ambasadorem Portugalii Jose’ Themide by przekazać mu - zgodnie z zaleceniami MSZ w Warszawie - kopię polskiego memorandum z kwietnia br. w sprawie przygotowań do konferencji bezpieczeństwa i współpracy. Podczas spotkania, oprócz wymienionej, szczerej zdaniem Chabasińskiego wymiany uprzejmości rozmawiano na tematy międzynarodowe, w tym o zbliżeniu Portugalii do Wspólnot Europejskich. $\mathrm{W}$ rozmowie $\mathrm{z}$ Chabasińskim minister Themide podkreślił, że zasadniczym celem polityki zagranicznej kraju jest utrzymanie więzi z terytoriami zamorskimi, choć w obecnych okolicznościach międzynarodowych będzie to trudne. Natomiast w polityce wewnętrznej - w okresie postsalazarowskim - wprowadzenie ostrożnych reform i utrzymanie stabilności władzy, zdając sobie sprawę z tego, że w kraju potężne wpływy mają armia i duchowieństwo. „Istnieją jednak w rządzie, wśród młodych wojskowych, na uniwersytetach, w życiu gospodarczym, prężne elementy podobne do grup Opus Dei w sąsiedniej Hiszpanii, które działają na rzecz zbliżenia Portugalii do Europy, a zwłaszcza do EWG z konsekwencjami politycznymi tj. transformacją reżimu politycznego. W Portugalii siły te zdają sobie sprawę z konieczności nieuchronnych przemian na odcinku więzi z tzw. terytoriami zamorskimi, w kierunku udzielenia im stopniowej autonomii" - zapowiedział (Chabasiński, 1970, A MSZ, Nabytek 27/77, wiązka 7).

Ambasador PRL w Rzymie, analizując rozmowę z Themide zwrócił uwagę, że wyzwaniem dla członkostwa Portugalii w EWG będzie zbliżająca się powoli akcesja Wielkiej Brytanii do Wspólnot Europejskich, gdyż już od wielu lat kraj jest nastawiony na kontakty gospodarcze właśnie z Londynem. „Zdając sobie sprawę, że wejście do EWG jest dla niej obecnie jeszcze zamknięte, Portugalia stara się w zakulisowych rozmowach o znalezienie formuły asocjacji w postaci ewentualnego traktatu handlowego. Nazwa nie gra z resztą roli, gdyż Lizbona gotowa jest do zaakceptowania każdej formuły, która by zabezpieczyła jej główne interesy i perspektywy korzyści z rozszerzonej wymiany wspólnorynkowej” (Ibidem) - dodał ambasador PRL w Rzymie.

Po podpisaniu Układu Preferencyjnego Hiszpania-EWG gospodarcza sytuacja kraju stopniowo podlegała korzystnym z punktu widzenia WE zmianom. W 1971 roku 
dostrzegły to polskie służby zagraniczne, które zapowiadały zbliżenie Madrytu do EWG.

26 września 1971 roku ówczesny dyrektor DEP. IV MSZ Stefan Staniszewski przesłał do Marszałka Sejmu PRL St. Gajewskiego pismo poufne na temat sytuacji w Hiszpanii oraz sugestie do rozmowy dla polskich dyplomatów z p. Baladiezem szefem Przedstawicielstwa Konsularno-Handlowego w Polsce, z którym miały się odbyć rozmowy na temat stosunków gospodarczych polsko-hiszpańskich. W piśmie dyrektor DEP. IV MSZ postawił tezę, że sytuacja gospodarcza w Hiszpanii jest ustabilizowana, a jej politykę zagraniczną określa $\mathrm{w}$ głównej mierze proces otwarcia na Europę zapoczątkowany w latach sześćdziesiątych. Dlatego też: „integracja z Europa, po osiagnnięciu przez Hiszpanię dość wysokiego stopnia rozwoju gospodarczego, stała się koniecznością i warunkiem dalszego rozwoju, stąd zbliżenie z EWG" (Staniszewski, 1971, A MSZ, Departament IV, zespół 17, wiązka 24).

W kolejnych latach, w związku ze zbliżającą się akcesją Wielkiej Brytanii, Irlandii oraz Danii do EWG (1973) Hiszpania nieskutecznie zabiegała o renegocjacje Układu Preferencyjnego z EWG zawartego w marcu 1970 roku. Jednak negocjacje o zawarcie układu stowarzyszeniowego nadal trwały, choć z powodów politycznych zaistniała groźba ich zerwania.

9 stycznia 1975 roku minister pełnomocny Przedstawicielstwa Konsularno-Handlowego w Hiszpanii Zygmunt Rut przesłał do dyrektora DEP. IV MSZ w Warszawie Henryka Solaka notatkę zatytułowaną: Na marginesie wywiadu prasowego ministra spraw zagranicznych Hiszpanii Pedro Cortina Mauri, który został udzielony agencji CIFRA. W wywiadzie minister Mauri wypowiedział się na temat trwających negocjacji jego kraju z EWG. Uznał on, że: ,jego rząd nie zgadza się z poglądem, że negocjacje z EWG zostały zerwane i że Hiszpania została w praktyce wyłączona z Europy. Przyznaje jednak, że istnieje zasadnicza rozbieżność poglądów na temat korzyści jakie Hiszpania odniosła z obowiązujących obecnie porozumień, a jakie państwa EWG. W Brukseli uważa się, że Madryt otrzymał więcej niż sam dał, a Hiszpanie skarżą się na trudności z eksportem swoich produktów rolnych do EWG" (Rut, 1975, A MSZ, Nabytek 16/81, DEP IV, wiązka nr 4).

Rok 1975 był dla Hiszpanii przełomowy. Za egzekucję wykonaną przez frankistowski reżim na pięciu baskijskich separatystach w 1975 roku oraz trwające liczne aresztowania przeciwników politycznych dyktatora Franco stosunki pomiędzy EWG a Hiszpanią zostały zerwane. Momentem przełomowym dla wznowienia dwustronnych rozmów o stowarzyszeniu Hiszpanii z EWG był zgon wieloletniego przywódcy Hiszpanii - generała Francisco Franco, który nastąpił 20 listopada 1975 roku. Jeszcze przed śmiercią, 30 października 1975 roku, schorowany i umierający Franco przekazał władzę królowi Juan Carlosowi. Sytuacja ta spotkała się z błyskawiczną reakcją dyplomatów polskich. Próbowali oni zakreślić aktualne perspektywy współpracy Hiszpanii z EWG.

1 listopada 1975 roku minister spraw zagranicznych PRL Stefan Olszowski sporządził pilną notatkę wewnętrzną zatytułowaną: Po zgonie Franco dotyczącą opisu sytuacji w Hiszpanii po zakładanym zgonie dyktatora. Zauważył on, że proces przemian demokratycznych w tym kraju może potrwać jeszcze długo, a rozwój wydarzeń zapowiadał następująco: 
- „choć gen. Franco odchodzi, a król Juan Carlos zostanie zaprzysiężony przez Kortezy faktyczną władzę $w$ tym kraju będzie sprawował rząd i stojące za nim siły proreżimowe; premierem nadal - przynajmniej przez jakiś czas będzie Carlos Arias Navarro;

- przekazanie władzy po śmierci Franco nastapi w sposób pokojowy; przewiduje się ewentualne wystapienia lewicowe i skrajnie prawicowe;

- rozwój polityczny kraju stopniowo będzie zmierzał do liberalizacji reżimu" (Olszowski, 1975, A MSZ, Nabytek 1681, DEP IV, wiązka nr 4, Hiszpania).

W dalszej części notatki Olszowski ocenił, że niezależnie od efektywności wprowadzanych zmian w kraju Hiszpania może liczyć na pomoc Stanów Zjednoczonych oraz Europy Zachodniej wraz z EWG i w bliższej bądź dalszej perspektywie na członkostwo w NATO i Wspólnotach Europejskich. „Z uwagi na swe znaczenie strategiczne Hiszpania stanowi ważne ogniwo w zachodnim systemie politycznym i militarnym, zwłaszcza przy uwzględnieniu całokształtu sytuacji na flance południowej i na samym Półwyspie Iberyjskim w związku z problemem portugalskim. Dlatego Hiszpania o ustabilizowanej sytuacji wewnętrznej ma dla zachodu znaczenie priorytetowe" (Ibidem).

W nowych okolicznościach, 28 lipca 1977 roku hiszpański rząd wystąpił do Wspólnot Europejskich z prośbą o przyjęcie kraju w poczet członków EWG. Fakt ten nie oznaczał jednak pełnego poparcia społeczeństwa hiszpańskiego dla akcesji kraju do Wspólnot Europejskich.

Jak informowała prasa polska, nastroje w Hiszpanii były różne. 23 września 1977 roku Polska Agencja Prasowa poinformowała, że: „20 września, podczas debaty parlamentarnej w Kortezach lewica hiszpańska zagłosowała przeciwko członkostwu kraju w EWG i postulowała politykę neutralności i nieangażowania się w żaden blok polityczno-wojskowy (PAP, 1977, s. 2).

Ostatecznie jednak rząd hiszpański obrał prowspólnotowy kierunek w polityce zagranicznej. W 1978 roku ustanowiono w Madrycie Ministerstwo Stosunków ze Wspólnotami Europejskimi i wyznaczono głównego negocjatora reprezentującego stronę hiszpańską. Był nim Calvo Sotelo. 19 grudnia 1978 roku Rada postanowiła rozpocząć negocjacje z Hiszpanią, które formalnie zainicjowano 5 lutego 1979 roku. Im bardziej zacieśniały się relacje pomiędzy Hiszpanią a EWG tym bardziej interesowali się nimi polscy dyplomaci.

4 maja 1981 roku ambasador PRL w Madrycie - Eugeniusz Noworyta przesłał do dyrektora DEP. IV MSZ Ryszarda Korczewskiego poufną notatkę opracowaną przez II sekretarza ambasady, Marka Grelę na temat perspektyw przystapienia Hiszpanii do EWG.

Już na pierwszej stronie dokumentu autor zaznaczył, że: „Hiszpania traktuje sprawę przystapienia do EWG w znacznym stopniu jako cel polityczny. Uważa się przy tym, że przystapienie do EWG potwierdziłoby «europejskość» Hiszpanii, a długofalowo byłoby korzystne gospodarczo" (Noworyta, 1981, A MSZ, Zespół Akt Nabytek 45/84, wiązka 1). W dalszej części notatki II sekretarz ambasady PRL w Madrycie odniósł się do wydarzeń z lutego 1981 roku, kiedy to w Hiszpanii przeprowadzono nieudaną próbę zamachu stanu autorstwa pułkownika Antonio Tejero Molina. W opinii Greli szybkie przystapienie kraju do EWG dałoby niezbędną gwarancję utrwalenia 
kruchych struktur demokratycznych i taka sytuacja nie miałaby miejsca. Jednak na drodze do członkostwa iberyjskiego kraju we Wspólnotach Europejskich stoi wiele innych, niepolitycznych przeszkód: polityka rolna, rybołówstwa, stanowisko Francji czy też ostatnie rozszerzenie EWG o Grecję z 1981 roku.

W dalszej części notatki Grela zauważył, że zacofanie gospodarki Hiszpanii w stosunku do gospodarek zachodnioeuropejskich oraz utrwalająca się recesja gospodarcza generują postawy sceptyczne wśród kół gospodarczych kraju, które świadome są odległych w perspektywie czasowej korzyści, jakie z pewnością Madryt odniósłby z członkostwa w EWG, a kosztami, które musi ponieść. Zdaniem Greli podpisanie traktatu o przystapieniu Hiszpanii do EWG mogłoby nastąpić nie wcześniej niż w połowie lat osiemdziesiątych. Okres ten miał być poprzedzony prawdopodobnie dziesięcioletnim okresem przejściowym. Autor przypomniał w notatce, że negocjacje pomiędzy Hiszpanią a EWG trwają od połowy lat siedemdziesiątych, jednak na ten moment są zawieszone, głównie za sprawą Francji. To właśnie jej prezydent Valéry Giscard d’Estaing stwierdził, że: „EWG powinna w pierwszym rzędzie zakończyć sprawy związane z jej pierwszym rozszerzeniem o Irlandię, Wielką Brytanię, Danię przed kolejnym rozszerzeniem Wspólnego Rynku" (Ibidem). Inne państwa, takie jak RFN, były zdania, że akcesję Madrytu do EWG powinny poprzedzić reformy wewnętrzne we Wspólnocie.

Według Greli, trudności w negocjacjach Hiszpania-EWG dotyczyły przede wszystkim:

- odmiennych interesów i oczekiwań Hiszpanii oraz „dziesiątki”, czyli warunków na jakich Hiszpania miałaby być do wspólnoty przyjęta;

- problemów wewnętrznych samej EWG - Komisja Europejska w tegorocznym raporcie wskazała, że reforma polityki rolnej powinna być dokonana przed przystąpieniem zarówno Hiszpanii, jak i Portugalii do EWG;

- interesów poszczególnych państw EWG lub wpływowych grup nacisku w tych krajach; obawy dotyczą głównie ochrony rynku pracy państw EWG oraz ich polityki rolnej;

- reakcji państw trzecich (Maroka, Tunezji, Izraela, Cypru, a więc krajów śródziemnomorskich), które obawiają się ograniczenia możliwości eksportu produktów rolnych, a także państw Ameryki Łacińskiej, które z kolei obawiały się ograniczenia możliwości eksportowych ich towarów do krajów zachodniej Europy;

- stosunku części ugrupowań politycznych i grup przemysłowców do warunków negocjacji Hiszpanii z EWG (Ibidem).

W końcowej części notatki polski dyplomata zauważył, że przedłużające się negocjacje Hiszpania-EWG, a więc niezrealizowanie jednego z głównych celów polityki zagranicznej Hiszpanii zdeterminowało Madryt do podjęcia akcesji do NATO.

Jak zauważa wspomniana już D. Bochańczyk-Kupka w 1980 roku nastąpiło znaczne spowolnienie negocjacji akcesyjnych pomiędzy Hiszpanią a WE spowodowane trzema wydarzeniami: deklaracją prezydenta Francji Valéry'ego Giscarda d'Estaingna z 5 czerwca 1980 r., mówiącą o konieczności uporania się ze skutkami I rozszerzenia Wspólnot Europejskich, spotkaniem Rady Europejskiej w Wenecji, w czerwcu 1980 roku tego roku, gdzie opowiedziano się za przeprowadzeniem zmian strukturalnych wewnątrz Wspólnoty, odmową Rady Ministrów przyjęcia terminu zakończenia negocjacji w 1983 r. (Bocheńczyk-Kupka, 20.08.2016). 
Pomimo tego, że 19 listopada 1981 roku Parlament Europejski uchwalił rezolucję wzywającą Radę Europejską i Radę Ministrów do ustalenia, najpóźniej do 1 stycznia 1984 roku terminu członkostwa Hiszpanii i Portugalii w EWG, dopiero na spotkaniu Rady Europejskiej w Stuttgarcie w dniach 17-19 czerwca 1983 roku pojawiła się propozycja rozszerzania Wspólnot Europejskich - zaplanowana na 1 stycznia 1986 r.

Z podobnymi problemami co Hiszpania borykała się także Portugalia. Negocjacje Lizbony z EWG rozpoczęły się w grudniu 1978 roku, a do 1980 roku trwał proces adaptacji prawa portugalskiego do wymogów Wspólnot. Dopiero w listopadzie 1982 roku uzgodniono wspólne stanowisko m.in., w sprawie przepływu kapitałów, siły roboczej itp.

W tym czasie w prasie polskiej informowano o trudnościach pojawiających się podczas trwających negocjacji między Hiszpanią i Portugalią a Wspólnotami Europejskimi. Publicyści sugerowali, że państwa członkowskie EWG nie myślą kategoriami wspólnotowymi, ale kierują się głównie narodowymi interesami.

6 grudnia 1983 roku w Atenach odbył się szczyt szefów państw i rządów EWG, który prasa polska szeroko komentowała. Jak informowała PAP trzydniowe spotkanie zakończyło się fiaskiem, a rządy państw członkowskich EWG nie osiągnęły porozumienia w najważniejszych kwestiach. Co ciekawe, sugerowano, że w Atenach nie opublikowano nawet wspólnego komunikatu końcowego spotkania. Różnice poglądów państw członkowskich dotyczyły głównie podziałów w sprawie budżetu oraz wspólnej polityki rolnej. Na łamach ,Życia Warszawy” zacytowano wypowiedź wiceprzewodniczącego Parlamentu Europejskiego - Egona Klepscha, który nazwał dzień 6 grudnia: czarnym dniem w historii integracji zachodnioeuropejskiej. Publicysta dziennika Wojciech Pomianowski, obrazując poziom emocji podczas szczytu w Atenach, zacytował wypowiedź premiera Grecji Andreasa Papandreu: „dziennikarzom nie mam nic miłego do powiedzenia" (PAP, 1983, s. 5). W opinii Pomianowskiego podczas spotkania państwa członkowskie EWG nie osiagnęły zgody w żadnym z kluczowych problemów, począwszy od reformy rolnej, a skończywszy na uzdrowieniu finansów w EWG. Zdaniem autora fiasko szczytu może przełożyć się na plany rozszerzania EWG o Hiszpanię i Portugalię, co zasugerował wspomniany Papandreu: „Jakiż to raj wspólnota jest dziś w stanie zaoferować Hiszpanii i Portugalii, jeśli nie potrafi rozwiązać swoich podstawowych problemów" (Ibidem).

12 czerwca 1985 roku zakończono niełatwe negocjacje pomiędzy Hiszpanią a EWG podpisaniem w Madrycie traktatu akcesyjnego. Kilka miesięcy później, 12 listopada 1985 roku zakończono również długie negocjacje pomiędzy EWG a Portugalią. W klasztorze Hieronimitów w Lizbonie podpisano traktat o członkostwie, który wszedł w życie 1 stycznia 1986 r.

\section{Po akcesji}

Od początku 1986 roku w prasie polskiej pojawiło się wiele interesujących artykułów poświęconych rozszerzeniu Wspólnot Europejskich o Hiszpanię i Portugalię.

Już 2 stycznia tego roku, na łamach „Trybuny Ludu” Polska Agencja Prasowa informowała, że Hiszpania i Portugalia zostały jedenastym i dwunastym członkiem 
Wspólnot Europejskich. W komunikacie prasowym poinformowano, że akcesję obu iberyjskich krajów poprzedziły niełatwe, ośmioletnie rokowania, a udział Hiszpanii i Portugalii w EWG jest równoznaczny: „ze śmiertelną walką na własnych rynkach wewnętrznych z potężniejszymi konkurentami z Francji, Anglii, Włoch, Belgii, Irlandii, Danii, Holandii, Luksemburga i Grecji” (PAP, 1986, s. 4). W organie prasowym PRL przestrzegano również, że nierówna konkurencja obu gospodarek - hiszpańskiej i portugalskiej, w porównaniu do gospodarek państw Wspólnot oraz zakładana rezygnacja ze środków protekcjonistycznych na towary importowane z EWG doprowadzi do wielomilionowych strat dla budżetów obu krajów.

Kilka dni później Rudolf Hoffman, na łamach tego samego dziennika, w artykule zatytułowanym: Droga Iberyjczyków przez Pireneje zwrócił uwagę, że w stolicach obu państw: Madrycie i Lizbonie, z dniem 1 stycznia 1986 roku usłyszeć było można huk fajerwerków, radości i braw, które znamionować miały nadzieję na uzyskanie przez oba kraje wielu korzyści z przystąpienia do EWG. Jego zdaniem iberyjskie kraje największe oczekiwania wiązały z pozyskaniem nowoczesnych technologii dla swoich zacofanych gospodarek. Liczyły także na pomoc dla hiszpańskiego oraz portugalskiego przemysłu stoczniowego, hutniczego i tekstylnego. Nie mniej ważne były także kredyty ze wspólnorynkowej kasy, które zasilić miały budżety obu krajów. W dalszej części artykułu Hoffman zasugerował, że akcesja Hiszpanii do EWG miała doprowadzić do zmiany nastawienia Hiszpanów do dziedziny militarno-obronnej: „Koła rządowe Madrytu są niemal pewne, że euforia wspólnorynkowa dopomoże gabinetowi Gonzalesa zmienić nieprzychylne w większości nastawienie społeczeństwa do członkostwa Hiszpanii w NATO" (Hoffman, 1986, s. 6).

W dalszej części artykułu autor podkreślił, że oprócz wielu zakładanych korzyści nowe kraje członkowskie będą musiały liczyć się z wieloma wyrzeczeniami. Jego zdaniem akcesja Hiszpanii do EWG w zakresie Wspólnej Polityki Rolnej skomplikuje sytuację rodzimych producentów oliwek i cytrusów. Postawi również w trudnej sytuacji tradycyjnych partnerów handlowych EWG: Izrael, Maroko, Tunezję, Turcję (Ibidem).

Do kolejnych trudnych zagadnień, z którymi miały się zmierzyć nowe kraje Wspólnot Hoffman zaliczył ograniczenie w dziedzinie produkcji rolno-spożywczej. Fakt ten wiązać się miał z koniecznością zamknięcia małych przemysłowych przedsiębiorstw, które nie wytrzymałyby konkurencji wobec EWG oraz z likwidacją flotylli rybackich. Wśród innych zagrożeń autor wymienił napływ obcego kapitału do obu krajów, który doprowadzić miał do stopniowej utraty tożsamości narodowej.

Z kolei Wojciech Pomianowski, na łamach innego opiniotwórczego dziennika - „Życie Warszawy” zwrócił uwagę, że w oficjalnych kołach Wspólnego Rynku akcesję obu iberyjskich krajów przyjęto z zadowoleniem i nadzieją. Podkreślił, że wiodącą opinią pojawiającą się w dyskusjach państw członkowskich EWG było przekonanie, że z aktualnym rozszerzeniem EWG wiążą się zarówno obietnice, nadzieje, ale również obawy. Wśród najważniejszych politycznych konsekwencji akcesji Hiszpanii i Portugalii do EWG autor wymienił:

- „przełamanie przez oba kraje: «kompleksu europejskiego zaścianka oraz umocnienie młodych, wciąż jeszcze kruchych i niestabilnych demokracji powstałych po wieloletniej erze frankizmu i salaryzmu»; 
- wzmocnienie pozycji EWG na arenie międzynarodowej;

- z uwagi na historyczne więzi między oboma krajami a Ameryką Lacińską - zintensyfikowanie kontaktów handlowych przede wszystkim z Latynoameryką, ale również z Afryką i Aseanem, a nawet Bliskim Wschodem" (Pomianowski, 1986, S. 5).

Autor zauważył, że wraz z rozszerzeniem EWG powstała nowa jakość polityczna, która ostatecznie doprowadzi do: ,przekształcenia EWG w trzecie mocarstwo światowe, a w przyszłości w planowane przez architektów EWG «Stany Zjednoczone Europy»" (Ibidem).

Przy wyliczeniu korzyści gospodarczych Pomianowski wymienił: powstanie olbrzymiego rynku zbytu w obu krajach zamieszkiwanego przez około 320 milionów ludzi, zwiększenie obrotów handlowych przez Wspólnoty w porównaniu do największych potęg gospodarczych: USA i Japonii oraz ułatwienie ekspansji gospodarczej EWG w niektórych regionach świata. Nie mniej ważnym argumentem było umożliwienie Hiszpanii i Portugalii modernizacji ich gospodarek za pośrednictwem pozyskanych, niezbędnych dla ich rozwoju gospodarczego, funduszy wspólnotowych.

Publicysta „Życia Warszawy” zwrócił też uwagę na drugą stronę medalu i wskazał liczne problemy zarówno dla nowych członków, jak i dla całej Wspólnoty Europejskiej. Wśród najważniejszych wymienił: mnogość tradycji i orientacji politycznych, tak dużej liczby państw skupionych w EWG, która - jak pokazuje przykład Grecji - nie wpłynęła pozytywnie na proces podejmowania decyzji w ugrupowaniu. Do kolejnych problemów nurtujących poszerzoną wspólnotę autor zaliczył długie okresy przejściowe ustalone $\mathrm{w}$ negocjacjach akcesyjnych oraz brak jednomyślności członków ugrupowania. Dotyczyły one chociażby zagadnień ekonomicznych związanych ze znoszeniem ceł i wyrównaniem poziomu cen. Ponadto wprowadzone zostały limity produkcyjne w rolnictwie, rybołówstwie, przemyśle, a także zniesiono ochronę rynków obu krajów. Podkreślił również, że po rozszerzeniu Wspólnot Europejskich w najbardziej konfliktogennym obszarze Wspólnej Polityki Rolnej, oprócz nadwyżek mleka i jego przetworów EWG będzie musiała poradzić sobie z nadwyżkami oliwy i wina.

Wśród innych problemów autor wymienił także: zwiększenie bezrobocia w krajach EWG, a także wzrost dysproporcji pomiędzy bogatą północą a biednym południem.

W kolejnych artykułach prasowych pojawiających się tuż po zjednoczeniu Hiszpanii i Portugalii ze Wspólnotami Europejskimi, Katarzyna Sobolewska-Myślik na łamach tygodnika „Polityka” zwróciła uwagę na zasięg procesu integracji europejskiej i jego rozmach. W artykule zatytułowanym Dziesięć plus $d$ wa podkreśliła, że w najbliższym dziesięcioleciu - w opinii włodarzy EWG - proces ten obejmie większość krajów starego kontynentu po to, aby osiagnąć jedność gospodarczą i polityczną na wzór Stanów Zjednoczonych Europy. Autorka przeanalizowała całą drogę do członkostwa obu iberyjskich krajów w EWG i uwypukliła najważniejsze gospodarcze wyzwania stojące zarówno przed EWG, jak i zainteresowanymi krajami. Wśród najważniejszych wymieniła: dostosowanie rolnictwa obu krajów do wymogów EWG, rozwój wspólnej polityki rybołówstwa WE, problem ochrony rodzimego przemysłu Hiszpanii. Zwróciła również uwagę na polityczne konsekwencje tego procesu, który miał jej zdaniem wpływ na transatlantyckie relacje pomiędzy USA a EWG. „USA miały porozumienia wojskowe z Hiszpanią frankistowska, jednak Hiszpania w ramach EWG to sojusznik 
jeszcze lepszy bo bardziej pewny" (Sobolewka-Myślik, 1986). W opinii autorki nie była to sytuacja przypadkowa: „gdzieś w powietrzu unosi się pogląd, że integracja w ramach EWG i NATO jest pełniejszą formą integracji europejskiej” (Ibidem).

Inny znany publicysta dziennika „Życie Warszawy” Wiktor Weegi na łamach artykułu: Portugalia - trudne wybory, ocenił, że po akcesji do EWG kraj w dalszym ciagu jest w gospodarczym kryzysie, gdyż członkostwo we Wspólnotach Europejskich niesie Portugalii nowe problemy, szczególnie w zakresie modernizacji gospodarki i dostosowania jej do standardów EWG. Autor, posługując się terminologią lekarską zaznaczył, że: ,jest to raczej leczenie ambulatoryjne, podczas gdy gospodarce portugalskiej potrzebna jest operacja" (Weegi, 1986, s. 5).

W latach 1962-1986 władza ludowa w Polsce na bieżąco śledziła proces akcesji obu iberyjskich krajów do EWG. Zdarzenia te oceniała przede wszystkim poprzez pryzmat skutków dla Polski, jak i dla bloku państw socjalistycznych. Początkowo polskie władze nie dawały szans Hiszpanii i Portugalii na ścisłą kooperację z EWG ze względu na dyktatury rządzące w obu krajach. Z biegiem czasu, kiedy Madrytowi i Lizbonie groziła długotrwała izolacja, w obu krajach rozpoczął się proces dostosowania ich gospodarek do wymogów Wspólnot. Jednak droga do członkostwa Hiszpanii i Portugalii w EWG była jeszcze długa i trudna. Oba kraje po ponad 20 latach starań uzyskały upragnioną akcesję.

W opinii władz PRL, oprócz kwestii gospodarczych, o akcesji Hiszpanii i Portugalii do Wspólnot Europejskich decydowały również kwestie polityczne. Władze w Polsce sugerowały, że warunkiem członkostwa Hiszpanii w EWG jest jej członkostwo w NATO, a w przypadku Portugalii zgoda Wielkiej Brytanii.

\section{Bibliografia}

Bernatowicz-Bierut G. (1978), Hiszpania we współczesnym świecie, Warszawa.

Bocheńczyk-Kupka D. (2006), Historyczno-polityczne uwarunkowania przystapienia Irlandii, Grecji, Hiszpanii, Portugalii do Wspólnot Europejskich, http://www.ue.katowice.pl/fileadmin/ user_upload/wydawnictwo/SE_Archiwalne/SE_38/08.pdf, 20.08.2016.

Chabasiński W. (1971), Archiwum MSZ (dalej A MSZ), Nabytek 27/77, wiązka 7, teczka: Portugalia 1971. Chabasiński do DEP. IV MSZ: pismo poufne Rozmowa z ambasadorem Portugalii, notatka z dnia 17 czerwca 1971, Rzym.

Długosz S. (1967), A MSZ Departament IV, zespół 17, teczka 211, wiązka 24. Długosz do DEP. IV MSZ, Stosunki polsko-hiszpańskie, notatka z kwietnia 1967.

Hajnicz A. (1962a), W kręgu starych przyjaciót, „Życie Warszawy” z dnia 20.07.1962.

Hajnicz A. (1962b), Ostatnie podanie, „Życie Warszawy” z 28 lipca 1962.

Dubiel P. (1967), Hiszpania 1967, „Tygodnik Demokratyczny” z 1 października 1967.

Hoffman R. (1986), Droga Iberyjczyków przez Pireneje, „Trybuna Ludu” z 10.01.1986.

Krasicki I. (1970), Hiszpania na rozdrożu, „Życie Warszawy” z 4 czerwca 1970.

Noworyta E. (1981), A MSZ, Zespół Akt Nabytek 45/84, wiązka 1, teczka: Hiszpania 1981, Noworyta do dyr. Dep. IV MSZ: Perspektywy przystapienia Hiszpanii do EWG, poufna notatka $\mathrm{z}$ dnia 4 maja, Madryt.

Ochęduszko J. (1963), A MSZ, DEP. IV, zespół 17, teczka nr 75, wiązka 32. Ochędeuszko DEP. IV MSZ: Tendencje rozwojowe gospodarki Portugalii w zwiazku z projektem przystapienia do $E W G$, tajna notatka z dnia 24 stycznia 1963, Paryż. 
Olszowski S. (1975), A MSZ, DEP. IV, Zespół Akt Nabytek 1681, DEP. IV, wiązka nr 4, Hiszpania 1975, Pilna notatka wewnętrzna sporządzona przez S. Olszowskiego: Po zgonie gen. Franco, z dnia 1 listopada, Warszawa.

PAP. (1977), Madryt, Kortezy - Nie lewicy hiszpańskiej wobec NATO, „Trybuna Ludu” z 23.09.1977.

PAP. (1983), Fiasko ateńskiego szczytu, „Życie Warszawy” z 7.12.1983.

PAP. (1986), Hiszpania i Portugalia wchodza do EWG, „Trybuna Ludu” z 2.01.1986.

Polański E. (1968), A MSZ, DEP. IV, zespół 17, teczka 211, wiązka 24. Polański do DEP. IV MSZ: Polityka zagraniczna Hiszpanii, notatka z dnia 23 grudnia 1968, Madryt.

Polański E. (1970), A MSZ, Zespół Akt Nabytek 27/76, wiązka 8, teczka EWG, EFTA, GATT, UZE, NORDEK, OECD. Polański do DEP. IV MSZ, notatka: Hiszpania a EWG, Madryt.

Pomianowski W. (1986), Dwie strony medalu. Zwiększona EWG, „Życie Warszawy” z 13.01.1986.

Rogulski S. (1967), A MSZ, Zespół 17, teczka 210, wiązka 24. Rogulski do Ochęduszki: Sytuacja gospodarcza Hiszpanii, notatka z dnia 14 lutego 1967, Madryt.

Rut Z. (1975), A MSZ, DEP. IV, Zespół Akt Nabytek 16/81, wiązka nr 4, teczka Hiszpania 1975, Rut do Dyr. DEP. IV MSZ: Na marginesie wywiadu prasowego ministra spraw zagranicznych Pedro Cortina Maurii, notatka z dnia 4 stycznia 1975, Madryt.

Sobolewka-Myślik K. (1986), Dziesięć plus dwa, „Polityka” z 11 stycznia 1986.

Staniszewski S. (1971), A MSZ, Departament IV, zespół 17, teczka 211, wiązka 24. Staniszewski do Gałaja: Sugestie do rozmowy z szefem przedstawicielstwa konsularno-handlowego w Polsce P. Baladieza Navarro, pismo poufne z dnia 28 września, Warszawa.

Szymczyński T. R.( 2009), Negocjowanie granic: Od ,dziewiatki” do „dwunastki”- Rozszerzenie południowe Wspólnot Europejskich (1981-1986), Poznań.

Weegi W. (1986), Portugalia - Trudne_wybory, „Życie Warszawy” z 24.01.1986.

\section{Streszczenie}

Zasadniczym celem artykułu było zaprezentowanie stanowiska władz Polskiej Rzeczpospolitej Ludowej wobec południowego rozszerzenia Wspólnot Europejskich o Hiszpanię i Portugalię w latach (1962-1986). W artykule przedstawiono m.in., tajną korespondencję pomiędzy polskimi dyplomatami przebywającymi na placówkach w Rzymie, Madrycie, Paryżu a DEP. IV Ministerstwa Spraw Zagranicznych PRL (Europa Zachodnia), w której przybliżono polskie oceny długiego i skomplikowanego procesu adaptacji obu iberyjskich krajów do wymogów wspólnotowych. W artykule zaprezentowano także reakcje prasy polskiej (m.in., „Trybuny Ludu”, „Życia Warszawy”, „Polityki”) na kooperację obu krajów z EWG.

Słowa kluczowe: integracja europejska, dyktatura, akcesja, PRL, Wspólnoty Europejskie, władza ludowa, EWG, Ministerstwo Spraw Zagranicznych, Ministerstwo Handlu Zagranicznego, prasa polska

\section{The Polish People's Republic's view on the EEC's enlargement to include Spain and Portugal (1962-1986)}

\section{Summary}

The main goal of this article is to present the attitude of authorities of Polish People's Republic towards the southern extension of the European Community of Spain and Portugal be- 
tween 1962 and 1986. In this article, among other things, the classified correspondence between the Polish diplomats who were allocated to posts in Rome, Madrid and Paris, and the fourth department of Polish People's Republic's Ministry of Foreign Affairs, has been presented. Those materials showed the Polish estimated assessment of a long and complicated process of adaptability of both Iberian countries to the requirements of the European Community. This article has also presented the responses of the Polish press (i.e. Trybuna Ludu, Życie Warszawy, Polityka) to the cooperation of both countries and EWG.

Key words: European integration, dictatorship, accession, Polish Peoples Republic, European Comminities, the people's government, Ministry of Foreign Affairs, Ministry of Foreign Trade, Polish press 